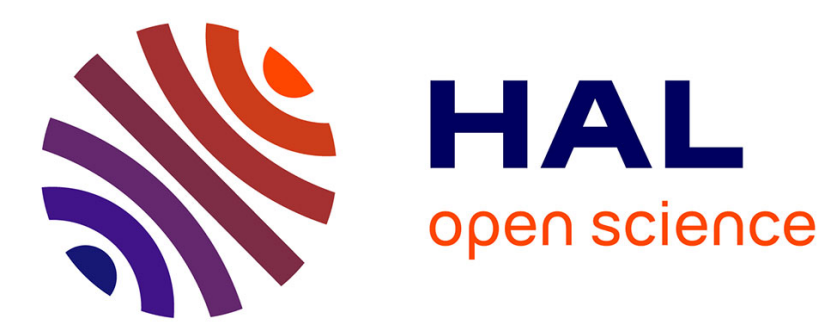

\title{
Spectrally resolved detection of NH3 at ppb level
}

\author{
J. Henningsen, T. Møgelberg, M. Hammerich
}

\section{To cite this version:}

J. Henningsen, T. Møgelberg, M. Hammerich. Spectrally resolved detection of NH3 at ppb level. Journal de Physique IV Proceedings, 1994, 04 (C7), pp.C7-499-C7-502. 10.1051/jp4:19947117 . jpa00253170

\section{HAL Id: jpa-00253170 https://hal.science/jpa-00253170}

Submitted on 1 Jan 1994

HAL is a multi-disciplinary open access archive for the deposit and dissemination of scientific research documents, whether they are published or not. The documents may come from teaching and research institutions in France or abroad, or from public or private research centers.
L'archive ouverte pluridisciplinaire HAL, est destinée au dépôt et à la diffusion de documents scientifiques de niveau recherche, publiés ou non, émanant des établissements d'enseignement et de recherche français ou étrangers, des laboratoires publics ou privés. 
JOURNAL DE PHYSIQUE IV

Colloque C7, supplément au Journal de Physique III, Volume 4, juillet 1994

\title{
Spectrally resolved detection of $\mathrm{NH}_{3}$ at $\mathrm{ppb}$ level
}

\author{
J. Henningsen, T. Møgelberg and M. Hammerich*
}

Danish Institute of Fundamental Metrology, Bldg. 307, Lundtoftevej 100, 2800 Lyngby, Denmark

* Rungsted Gymnasium, Stadion Alle 14, 2960 Rungsted Kyst, Denmark

\begin{abstract}
Photoacoustic detection of $30 \mathrm{ppb}$ ammonia in air is demonstrated with a signal to noise ratio of 40 , using a $400 \mathrm{MHz}$ tunable $\mathrm{CO}_{2}$ laser as radiation source. Interference from $\mathrm{CO}_{2}$ is controlled by monitoring near the Doppler limit and by using phase information to separate the two signals. Wall adhesion is studied quantitatively. It is shown that the walls constitute a reservoir of fixed size, which is filled up at a rate proportional to the $\mathrm{NH}_{3}$ concentration.
\end{abstract}

\section{Introduction}

Ambient air contains ammonia in concentrations which typically range from $0.1 \mathrm{ppb}$ over sea water, to tens of $\mathrm{ppb}$ in regions of intensive livestock breeding. It has been known for a long time that photoacoustics, using a $\mathrm{CO}_{2}$ laser as radiation source, will in principle provide the required sensitivity for monitoring these concentrations. However, two problems have blocked the way for practical use of this scheme. The first problem is associated with the presence of $\mathrm{CO}_{2}$ in the atmosphere. The line strength of a strong $\mathrm{NH}_{3}$ line is typically 5000 times larger than that of the $\mathrm{CO}_{2}$ hot band transitions which will absorb at the center of each $\mathrm{CO}_{2}$ laser line. Hence, an ambient $\mathrm{CO}_{2}$ concentration of $400 \mathrm{ppm}$ will be equivalent to an $\mathrm{NH}_{3}$ concentration of about $80 \mathrm{ppb}$ and thus lead to a sizeable interference problem. This can be dealt with by using isotopic $\mathrm{CO}_{2}$ lasers [1], by using Stark modulation techniques [2], or by measuring in a number of different $\mathrm{CO}_{2}$ lines [3] and combining the results. We here describe a different approach which is technically considerably simpler, while still providing the required discrimination.

The second problem is related to the strong tendency of $\mathrm{NH}_{3}$ to stick to surfaces. The photoacoustic signal is generated in a cell, and it is very difficult to ensure that the concentration in the gas phase inside the cell is representative of the source. Furthermore, the equilibrium between the gas phase and the walls may be approached with excessively large time constants. In fact, the absence of equilibrium sometimes have lead to quite exaggerated claims concerning the sensitivity.

In this paper we present a solution to the $\mathrm{CO}_{2}$ interference problem based on the use of a widely tunable $\mathrm{CO}_{2}$ laser combined with exploitation of photoacoustic phase information. The method is subsequently used for performing quantitative studies of wall adhesion.

\section{The photoacoustic setup}

The radiation source is a small $400 \mathrm{MHz}$ tunable $\mathrm{CO}_{2}$ laser, electrically pulsed at $800 \mathrm{~Hz}$, similar to that which has been previously used for detecting $\mathrm{NH}_{3}$ at ppm concentrations in power plant emission [4]. It provides $400 \mathrm{~mW}$ at the center of the $9 \mathrm{R} 30$ line, and in the Doppler limit its tuning 
range allows recording of the resolved rotation-vibration absorption profile of the $s R(5,0)$ ammonia transition at an offset of $-190 \mathrm{MHz}$.

The photoacoustic cell is shown in Fig.1. It consists of a $20 \mathrm{~cm}$ long organ pipe of stainless steel, resonant at $800 \mathrm{~Hz}$, and contained in a glass housing with spherical baffles and ZnSe Brewster windows. A Knowles microphone is mounted behind a hole at the center of the acoustic resonator. The signal was preamplified, and the amplitude and phase were measured with a dual phase lock in amplifier.

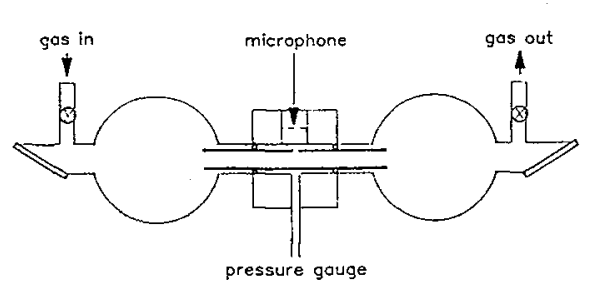

Fig.1 Resonant photoacoustic cell.

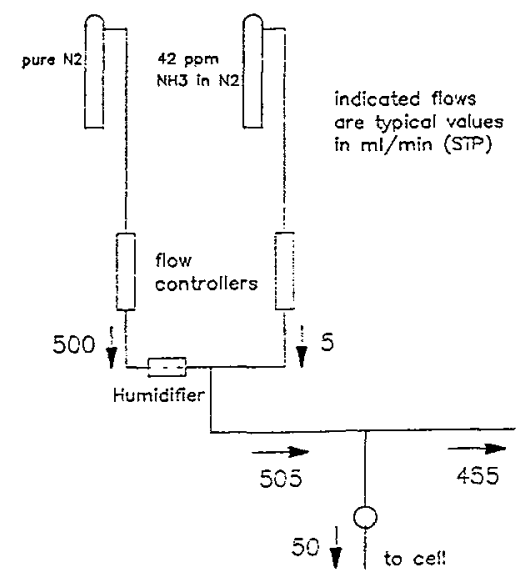

Fig.2 Flow system for generating low concentrations by dynamic mixing.

\section{Gas handling system}

Controlled concentrations of $\mathrm{NH}_{3}$ in $\mathrm{N}_{2}$ or in air were established by dynamic mixing, using a system of calibrated mass flow controllers shown in Fig.2. A certified mixture of $42 \mathrm{ppm}$ of $\mathrm{NH}_{3}$ in $\mathrm{N}_{2}$, provided by UCAR, was supplied to either of two controllers with a maximum flow rate of 10 and $100 \mathrm{ml} / \mathrm{min}$ STP, and a resolution of $1 \%$. This gas was diluted by either $\mathrm{N}_{2}$ or air supplied from a controller of flow rate $500 \mathrm{ml} / \mathrm{min}$ STP. The flows were combined, and allowed to flow freely into the atmosphere. Gas to the cell was sampled at a rate between 50 and $250 \mathrm{ml} / \mathrm{min}$ STP through a needle valve from a tee inserted in the combined flow. In this way the $\mathrm{NH}_{3}$ concentration could be changed without affecting the pressure in, or the flow through the cell.

Since the photoacoustic responsivity as well as the wall effects are influenced by the presence of water $[3,5]$, provision was made for humidifying the buffer gas by letting it bubble through water after leaving the flow controller. The pressure was measured at the center of the cell with an absolute pressure meter of $0.1 \mathrm{mBar}$ resolution, calibrated against a mercury manometer.

Using this system, and allowing the necessary time for equilibrium with the walls of the cell, reproducible and reliable measurements could be made. It should be strongly emphasized that when attempting to generate low concentrations by stepwise dilution in containers, wall effects imply a high risk of arriving at concentrations quite far from those aimed for.

\section{Calibration}

All flow controllers were calibrated using a water displacement flow meter. Requiring the flow rate to be at least 10 times the resolution limit, the lowest concentration that could be generated was $84 \mathrm{ppb}$. Calibration of the photoacoustic responsivity was performed at $27.5 \mathrm{mBar}$ and room temperature with moist $\mathrm{N}_{2}$ as buffer gas over the range 84 to $7000 \mathrm{ppb}$, with results as shown in Fig.3. Within the experimental scatter of the data points, the response is linear in concentration over this range, as expected. The measured sensitivity of $0.17 \mu \mathrm{V}$ per ppb, combined with an rms noise limit of 
$0.14 \mu \mathrm{V}$, leads to a minimum detectable concentration of $0.8 \mathrm{ppb}$ at a signal to noise ratio of 1 . Increasing the pressure to $150 \mathrm{mBar}$ will increase the photoacoustic response by a factor of 4 , and hence improve the sensitivity significantly. However, the associated line broadening will aggravate the problems associated with $\mathrm{CO}_{2}$ interference, and $27.5 \mathrm{mBar}$ was found to provide a convenient compromise between sensitivity and selectivity.

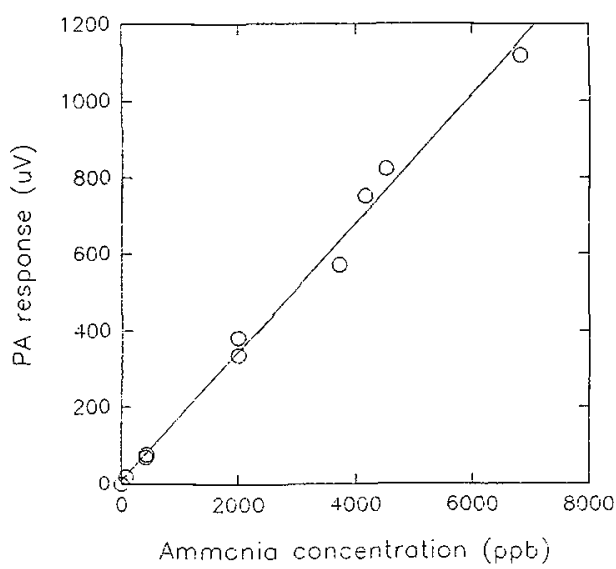

Fig.3 Photoacoustic response as a function of $\mathrm{NH}_{3}$ concentration with wet $\mathrm{N}_{2}$ as buffer gas.

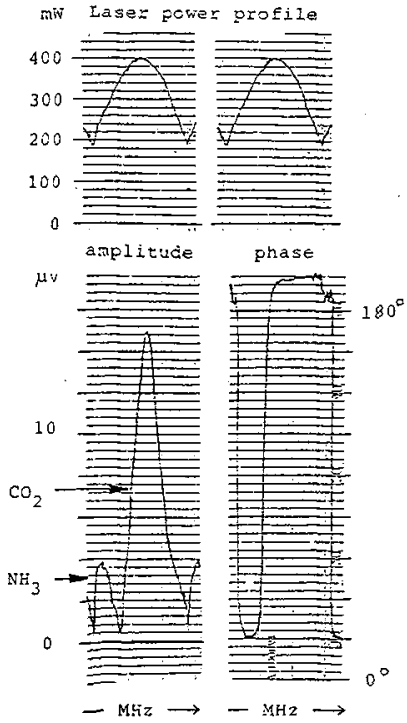

Fig.4 Photoacoustic amplitude and phase as a function of frequency tuning.

\section{Selectivity}

Recordings of photoacoustic amplitude and phase are shown in Fig. 4 for about $30 \mathrm{ppb} \mathrm{NH}_{3}$ in moist air. At the center of the tuning range, the signal is completely dominated by $\mathrm{CO}_{2}$, present in the air at a concentration of about $400 \mathrm{ppm}$. The amplitude is $14.5 \mu \mathrm{V}$, equivalent to $85 \mathrm{ppb}$ of $\mathrm{NH}_{3}$, and the phase is at $196^{\circ}$. Owing to kinetic cooling $[4,3]$ the $\mathrm{CO}_{2}$ signal is $0.6 \mathrm{~ms}$ delayed relative to the $\mathrm{NH}_{3}$ signal, corresponding to a phase lag of $170^{\circ}$. Thus, as the laser frequency is scanned towards negative offset, the phase of the combined signal will experience a sudden change, being eventually completely controlled by $\mathrm{NH}_{3}$. At the offset where the combined phase changes most rapidly, the combined amplitude becomes almost zero, reflecting the nearly complete destructive interference between the photoacoustic signal generated by $\mathrm{CO}_{2}$, and that generated by $\mathrm{NH}_{3}$. It is precisely this feature that greatly facilitates the discrimination between the two signals, and thus provides the selectivity.

\section{Wall absorption}

The tendency of $\mathrm{NH}_{3}$ to stick to surfaces is known to be the major problem in instrumentation for dynamic monitoring of $\mathrm{NH}_{3}$. Some semi quantitative experiments have been performed, using a leaf chamber technique [6]. We have studied the problem by applying a step change in the input concentration to the cell, starting from zero concentration. Initially, the $\mathrm{NH}_{3}$ molecules will settle on the wall in the vicinity of the entrance, and few of them will survive to the acoustic resonator and be detected. As the wall gradually becomes saturated, the photoacoustic response will increase, and eventually reach a steady level. If the response is plotted as a function of time, the area in the graph between the asymptote and the actual response curve is a measure of the number of molecules lost to that part of the wall which is located between the gas entrance and the detection region. 
Measurements have been carried out at concentrations of $423 \mathrm{ppb}$ and $4516 \mathrm{ppb}$, in both cases with wet $N_{2}$ as buffer gas. The cell was prepared by flushing with moist $\mathrm{N}_{2}$ for several hours. From the measured flow rate and the known responsivity it is straightforward to evaluate the number of molecules lost to the wall in the two cases. At the lowest concentration, saturation was not reached during the 6 hours duration of the experiment. In this case, the photoacoustic signal is assumed to approach the asymptote exponentially, with a time constant of 3 hours, as determined by the slope of the data for times larger than 180 minutes.

Using this method, the loss to the wall was found to be 0.45 and $0.39 \mu \mathrm{Mol}$ respectively, both with an estimated uncertainty of about $20 \%$. Considering the factor of 10 difference between the input concentrations, we may conclude that the wall constitutes a reservoir of fixed size, and that it is filled up at a rate which is essentially proportional to the concentration of $\mathrm{NH}_{3}$ in the gas phase.

With a total surface area of about $360 \mathrm{~cm}^{2}$, we find that each $\mathrm{NH}_{3}$ molecule occupies an area of $3.2 \times 3.2 \AA^{2}$. This suggests that a monolayer is formed on the wall, and that the existence of this layer effectively prevents further deposition.
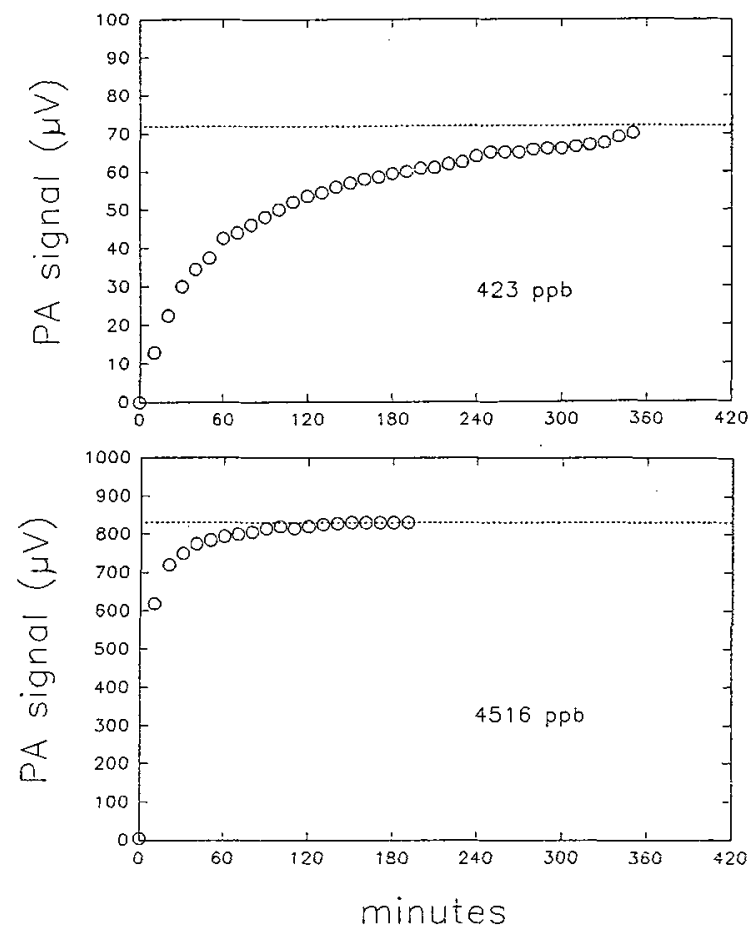

Fig.5 Photoacoustic response as a function of time for a step function in iuput concentration applied at $t=0$.

\section{Conclusion}

It is possible to measure $\mathrm{NH}_{3}$ at sub ppb levels in air, using a normal isotope $\mathrm{CO}_{2}$ laser with enough tunability to allow recording of Doppler limited absorption profiles. Discrimination against absorption from $\mathrm{CO}_{2}$ in the air is provided by photoacoustic phase information. The walls of the cell constitute a reservoir of fixed size for $\mathrm{NH}_{3}$ molecules. It is filled up at a rate proportional to the gas phase concentration, and this leads to very long time costants at low concentrations.

\section{References}

[1] V. S. Starovoitov and S. A. Trushin, preprint

[2] H. Sauren, D. Bićanić and K. van Asselt, Infrared Physics 31, 475-484 (1991).

[3] R. A. Rooth, A. J. L. Verhage, and L. W. Wouters, Applied Optics 29, 3643-3653 (1990).

[4] A. Olafsson, M. Hammerich, J. Bülow and J. Henningsen, Applied Physics B 49, 91-97 (1989).

[5] H. Sauren and D. Bićanić, Analytical Instrumentation (1991).

[6] H. Sauren, B. van Hove, W. Tonk, H. Jalink, and D. Bićanić, in "Monitoring of Gaseous Pollutants with Tunable Diode Lasers", Kluwer, Dordrecht (1989). 